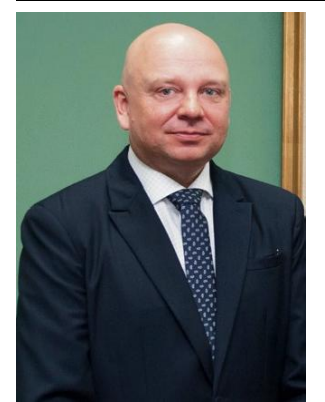

\author{
УДК 334.758:005.591.6(4)ЕС \\ https://doi.org/10.47612/978-985-7149-55-1-2020-171-174
}

Бартош Мицкевич, доктор экономических наук, профессор, декан экономического фракультета

Павел Мицкевич, доктор экономических наук, профессор, кафредра менеджмента предприятий экономического фракультета Западнопоморский технологический университет, г. Щецин, Польша

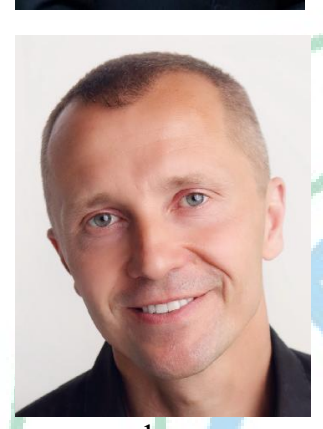

\title{
Формирование кластерно-сетевой
}

\section{A. С -модели инновационного партнерства стран Европейского союза}

На современном этапе единая аграрная политика представляет собой совокупность форм и методов упорядоченной деятельности государств Европейского союза и их институтов, направленных на формирование рационального и устойчивого развития сельского хозяйства и его территорий в рамках европейского сообщества. Единая аграрная политика (далее - ЕАП) обеспечивает эффективное сельскохозяйственное производство и продовольственную безопасность за счет использования субсидий и стабильных цен на продукты питания (на минимальном уровне). Она определяет главную роль ЕС в мировом производстве и торговле продовольственными продуктами: на долю стран ЕС приходится 17 \% мирового экспорта продуктов питания; ЕС занимает второе место как мировой экспортер молочных продуктов, свинины и третье место - по экспорту птицы и зерна [1].

Аграрный сектор ЕС продолжает расширять сельскохозяйственное производство для удовлетворения возрастающего мирового спроса на продовольствие, который, по прогнозам продовольственной и сельскохозяйственной организации (ФАО), к 2050 г. увеличится на $70 \%$ [2].

Европейская комиссия обозначила актуальные направления развития ЕАП: экономическое (обеспечение продовольственной безопасности; совершенствование механизмов, снижающих колебание цен на сельскохозяйственную продукцию и продовольствие; необходимость мер, позволяющих быстро и гибко преодолевать последствия экономического кризиса, и т. д.); окружающая среда (уменьшение эмиссии парниковых газов; сохранение и восстановление плодородия почвы, рачительное использование ресурсов воды, борьба с загрязнением окружающей среды; сохранение среды обитания и биологического разнообразия и др.); социальное (обеспечение жизнеспособности сельских районов; сохранение разнообразия сельского хозяйства и др.) [4].

Приоритетами ЕАП ЕС признаются продовольственная безопасность и развитие органического сельского хозяйства. Органическое производство более устойчивое, наносит меньший вред окружающей природной среде, адаптируется под климатические изменения и поддерживает приемлемый уровень плодородия на долгосрочную перспективу. Базовые стандарты органического хозяйства установлены Международной федерацией экологического сельскохозяйственного движения (IFOAM) и их сущность проявляется в следующих принципах: экологичности (органическое сельскохозяйственное производство основывается на существовании естественных экосистем и циклов, работая, сосуществуя с ними и поддерживая их); здоровья (органическое сельскохозяйственное производство поддерживает и улучшает состояние почвы, растений, животных, людей и планеты как единого и неделимого целого); заботы (управление органическим сельскохозяйственным производством должно носить предупредительный и ответственный характер для защиты здоровья и благополучия нынешних и будущих поколений и окружающей среды); справедливости (органическое сельскохозяйственное производство должно основываться на отношениях, гарантирующих справедливость с учетом общей окружающей среды и жизненных возможностей).

Согласно приоритетам ЕАП, страны - члены ЕС, придерживаясь единой стратегии развития сельского хозяйства, могут реализовывать собственную аграрную политику, но при этом основные ее параметры должны соответствовать правилам Союза. Для повышения эффективности производства продовольствия в ЕС взят курс на стимулирование научных исследований и инновационных разработок в аграрной сфере. Знания становятся решающим фактором повышения продуктивности европейского сельского хозяйства и фактором упрочения позиций ЕС на мировых рынках продовольствия. Активизация научно-инновационной деятельности в этой области, стимулирование инноваций и придание импульса инновационному развитию аграрного производства находятся в русле новой стратегии развития ЕС до 2020 г., предусматривающей устойчивый рост с использованием «умных технологий» (a Strategy for Smart, Sustainable and Inclusive Growth), что обеспечит Евросоюзу преимущество в конкурентной борьбе на международном рынке.

Решение проблем глобальной и региональной продовольственной безопасности в условиях изменения климата требует разработки новых подходов к ведению сельского хозяйства. Это «климатически умное сельское хозяйство», основанное на необходимости ведения сельскохозяйственной деятельности, которая повышает производительность, обладает повышенной устойчивостью к изменению климата и способствует сокращению выбросов парниковых газов. 
Сельское хозяйство Евросоюза в ХХІ в. должно быть инновативным и экологичным, с большим количеством «зеленых технологий», которое сможет удовлетворить потребности населения в высококачественных продуктах питания и альтернативных видах топлива, сохранив при этом конкурентоспособность на мировых рынках. В системе ФАО успешно функционируют международные информационные системы мониторинга для анализа и прогнозирования сельскохозяйственного производства, пищевой промышленности, продовольственных рынков и агробизнеса.

В современной экономике кластерная политика является одним из ключевых приоритетов инновационного развития экономик стран Евросоюза, в том числе аграрной политики. Основы современной кластерной политики в Европе сформулированы в 2006 г. в Манифесте кластеризации в странах ЕС, в 2008 г. - в Сообщении комиссии европейских сообществ «На пути к кластерам мирового уровня в ЕС: внедрение расширенной инновационной стратегии», что дает возможность повысить конкурентоспособность отдельных членов Евросоюза на мировых рынках.

Определяющим фактором создания инновационного кластера является способность поддерживать непрерывность процесса создания и освоения инноваций посредством интеграции субъектов как минимум трех институциональных сфер: бизнеса, университетов и государства. Модель инновационного кластера характеризуется следующими качественными параметрами: связность кластера, синергетический эффект, базовый элемент кластера и его структурные элементы, ядро кластера (центры дохода) и резервы роста. Функционирование кластера повышает конкурентоспособность компаний тремя путями: через рост производительности труда, через повышение способности к инновациям и через возникновение новых предприятий, что способствует как внедрению, так и расширению кластера.

На данном этапе в ЕС насчитывается более 2 тыс. кластеров, в которых занято около $40 \%$ работников. Кластеризацией полностью охвачена промышленность Дании, Финляндии, Норвегии, Швеции и Нидерландов. Благодаря кластеризации экономики Финляндия занимает ведущие места в мировых рейтингах конкурентоспособности: располагая всего 0,5\% мировых лесных ресурсов, обеспечивает $10 \%$ мирового экспорта продукции деревопереработки и $25 \%$ экспорта бумаги.

Примеры наиболее успешного развития кластерных инициатив в Европейском союзе среди старых членов: Австрия среди малых стран (особенно кластерная инициатива в земле Верхняя Австрия, где термин «кластер» был эффективно использован как «бренд» для улучшения имиджа региона и привлечения прямых иностранных инвестиций в местные предприятия), Великобритания (Шотландия), Испания (Каталония), Германия (Северный Рейн-Вестфалия). В Словении принята стратегия повышения конкурентоспособности промышленности на основе функционирования кластеров, создана ассоциация «Автомобильный кластер Словении», в которую вошли 22 предприятия и 5 научных и образовательных учреждений.
На данном этапе основная инициатива, ставящая целью развитие трансграничных кластеров в Европе, это программа TACTICS (Transnational Alliance of Clusters Towards Improved Cooperation Support) Транснациональный кластерный альянс в целях поддержки усиления кооперации (сотрудничества). TACTICS объединяет семь ведущих европейских кластерных агентств, которые отвечают за развитие кластеров. Данные структуры призваны активно взаимодействовать с целью выработки стимулирующих политик и инструментов реальной поддержки развития кластеров на уровне ЕС. Было определено шесть приоритетных направлений, которые способствуют переходу от обсуждения практики развития промышленно-инновационных кластеров в плоскость реального сотрудничества между различными европейскими кластерами.

Важной характеристикой кластера является возникающая на его территории благоприятная среда для интенсивного общения участников инновационного процесса, что является сильным стимулом для творчества. Анализ показал, что в Европейском союзе примерно каждая четвертая компания (24\%) с численностью занятых свыше 20 чел. работает в кластерной среде, характеризуемой тесной кооперацией с другими местными компаниями и устойчивыми связями с локальной бизнес-структурой.

Интенсивно развивается налаживание сетей в Швейцарии, Исландии и Норвегии. Уровень и интенсивность сетевых связей наиболее высоки в северных регионах EC: Финляндии, Швеции, Дании и Норвегии. Наилучшим образом интеграционные процессы происходят: между компаниями (среди среднего и малого бизнеса $70 \%$ компаний, среди крупных компаний - 60, среди недавно открытых - 40); между компаниями и государственной администрацией (64); между компаниями и различными финансовыми институтами (61); между компаниями и университетами (55); между компаниями и государственными лабораториями (36), а также между компаниями и исследовательскими центрами (36\%).

В целом взаимодействие между кластерами в Европейском союзе сводится к обмену опытом и знаниями, поиску надежных партнеров для выхода на новые рынки. Этому способствуют различные межгосударственные площадки, программы и инициативы. Необходимо отметить, что часть инициатив ЕС по инновационному кластерному развитию основана на использовании доступных финансовых инструментов, таких как кредиты, которые осуществляет Европейский инвестиционный банк (European Investment Bank).

Таким образом, сегодня многие страны разрабатывают государственные программы и имеют огромные затраты на «выращивание» кластеров. Такие программы практически разработали все страны ЕС. Они реализуются в соответствии с решениями Лиссабонской стратегии с целью внедрения в странах - членах ЕС экономики знаний, способной на основе инновационных кластеров обеспечить конкурентоспособность на мировом рынке.

Согласно рейтингу стран по Сводному индексу инновационного развития Innovation Scoreboard 2019, 
рассчитано изменение скоростей инновационного развития как внугри ЕС, так и относительно основных международных конкурентов. Индекс инновационного развития рассчитан на основе 27 показателей, по результатам которого распределены страны по четырем группам: «инновационные лидеры» (120\% от среднего показателя по ЕС), «сильные инноваторы» (90-120), «средние» (50-90) и «скромные инноваторы» (ниже 50 \%).

Рост инновационного индекса на $8,8 \%$ по сравнению с 2011 г. (благодаря положительной динамике в подготовке докторантов, международных научных публикаций, проникновению высокоскоростного интернета) продемонстрировали 25 стран - членов ЕС. Швеция, Финляндия, Дания и Нидерланды - традиционные инновационные лидеры ЕС. Великобритания и Люксембург, которые на протяжении последних лет входили в группу «инновационных лидеров», теперь отнесены к группе «сильных инноваторов», Эстония из «средней» поднялась в «сильную группу», Румыния и Словения значительно снизили позиции. Формирование объединенной Европы способствовало ее становлению как центра силы на глобальном научно-техническом рынке. Достойно конкурировать на мировых рынках помогают инновационные технологии и производимая продукция. Кластеры позволяют в полной мере реализовать тесное сотрудничество государства с частным бизнесом и получить реальный результат и эффект.

Проведенный анализ стратегий и инновационных программ во многих развитых странах показал, что имеются их отличительные особенности. При поддержке Европейской комиссии создан ряд организаций, оказывающих информационную, образовательную, консультационную, а также маркетинговую поддержку территориальным кластерам, - Европейская кластерная обсерватория (European Cluster Observatory), Европейская группа по кластерной политике (European Cluster Policy Group), Европейский кластерный альянс (European Cluster Alliance), Кластерная инновационная платформа (Cluster Innovation Platform). Вхождение в сети обеспечивает эффективный способ доступа к знаниям, инновациям, дополнительным возможностям и ресурсам, которые отсутствуют внутри самого предприятия и не могут быть получены другим способом, ускоряют и расширяют возможности выхода на новые рынки.

Крупнейшие инновационные кластеры ЕС:

1. Косметическая долина (Франция) - над инновациями работают 7 университетов, 136 колледжей, 200 исследовательских лабораторий. Годовая выручка 11 млрд евро.

2. Саксонская кремниевая долина в Дрездене (Германия) - функционирует более 300 компаний с численностью персонала в 30 тыс. чел.

3. Сассуоло в регионе Эмилия - Романия (Италия) это 200 предприятий керамической плитки, 60 \% всех производителей в стране, при этом происходит постоянная техническая инновация обжиговых печей.

4. ВіоМ в Мюнхене (Германия) - более 300 компаний, 5 инкубаторов и более 10 институтов заняты биотехнологиями и фармацевтикой.
5. Agro Business Park (Дания) - имеет $75 \%$ от всего оборота пищевой продукции страны.

6. BRAINPORT в Эйндховен (Нидерланды) - генерирует $14,5 \%$ ВВП и считается «локомотивом» экономики страны.

В Польше действуют примерно 140 кластеров, которые представляют 27 секторов различных специализаций экономики и сформированы в секторах IT, энергетики и возобновляемых источников энергии, строительстве, в медицинской промышленности и туризме. Значительное число кластеров создано по бизнес-услугам, в металлургической промышленности и в технологических производствах. Семь кластеров имеют национальный статус: «Авиационная долина», «Польский алюминий», Mazowiecki Klaster ЮТ, Interizon (ICT), Wschodni Klaster Budowlany (строительство), Klaster Obrobki Metali (металлообработка), Zachodniopomorski Klaster Chemiczny «Zielona Chemia» (химический).

Концепция формирования национального кластера связана с реализацией целей Стратегии «Европа-2020» и соответствует Концепции Европейской комиссии «умной специализации» (смарт-специализации), которая намерена сконцентрировать усилия и ресурсы на конкретных приоритетах. Сводный инновационный индекс в 2019 г. в Польше относительно ЕС равен 58,9. Благоприятная среда для инноваций, развитие предпринимательства и рост производительности труда оказали наибольшее влияние на его величину.

Инновационное развитие экономики и торговля агропищевыми продуктами являются результатом присоединения Польши к ЕС и устранения ограничений в торговле. Экспорт продовольствия в 2019 г. составил примерно на 32 млн евро. Фактические и прогнозные показатели инновационного развития экономики Польши отражают положительную динамику. В 2020 г. валовые внутренние расходы на НИОКР (в \% к ВВП) составят $1,21 \%$ (в ЕС-1,7\%).

Ключевым элементом инновационной политики становится «умная специализация» [3]. В Европе расширение пространственных границ экономической активности территорий достигается с помощью концепции «умной специализации». Практическая реализация осуществляется на основе специальной электронной платформы Smart Specialization Platform, которая обеспечивает возможность получения информации, методологий, экспертизы и консультации национальных и региональных директивных органов, способствует взаимному обучению и межнациональному сотрудничеству. Регистрация на платформе открыта для стран и регионов ЕС, а также для других стран и регионов. В системе зарегистрировано 20 стран и 178 регионов.

В настоящее время действует 13 Кластерных партнерств, учрежденных Европейской комиссией:

европейская ассоциация светотехнических кластеров;

европейское партнерство аэрокосмических кластеров;

европейское партнерство кластеров в области коммуникаций и информационных технологий; 
европейское партнерство кластеров в области спорта;

европейский консорциум полупроводниковых кластеров;

партнерство кластеров в области продуктов питания; партнерство кластеров в области текстильной промышленности;

партнерство кластеров в области гидроэнергетики; кластеры исследований в области борьбы со старе-

нием населения;

международная сеть чистых технологий;

фотоника и инновационные покрытия;

персонализированное здравоохранение;

эффективное использование европейских природных ресурсов [5].

Создание кластеров экономики, отвечающих принципам «умной специализации», обеспечило бы развитие новых систем производства и полноценный переход к новому технопромышленному укладу за счет использования ключевых способствующих технологий (key enabling technologies - KET), таких как использование новых материалов, электронных систем и новых типов энергии.

Одним из инструментов эффективной цифровизации производства инновационно ориентированной кластерной структуры является стратегия CALS (Continuos Acquisition Acquisition and Life Cycle Support) - создание единого информационного пространства для всех участников жизненного цикла технологической инновации. При практической реализации стратегии CALS инновационно ориентированная кластерная структура использует различные группы методов, называемых CALS-технологиями. Автоматизированный подход к построению системы управления инновационно ориентированной кластерной структурой приводит к тому, что система становится многоуровневой, охватывая различные уровни.

Для целей управления и эффективности деятельности инновационно ориентированной кластерной структуры используются различные классы информационных систем. Применяются MES-системы (Manufacturing Execution System), предназначенные для управления производственными процессами; MRP-системы (Material Requirements Planning), охватывающие процессы планирования потребности в материалах; ERP-системы (Enterprise Resource Planning), обеспечивающие интеграцию процессов управления производством, трудовыми ресурсами, финансами и активами; PDM-системы (Product Data Management), позволяющие управлять всей информацией о продукции; CRM-системы (Customer Relationship Management), регламентирующие процессы управления взаимоотношениями с клиентами.

В современных условиях формирование цифровой среды повышает эффективность функционирования кластерной структуры. В инновационной кластерной структуре, осуществляющей реализацию инноваций в производственной сфере и использующей высокоавтоматизированные организационно-производственные звенья, это достигается за счет разработки интегрированной системы управления. Подобная система, реализуя совокупность $C A L S$-технологий, позволяет управлять совокупностью бизнес-процессов, протекающих в различных сферах деятельности инновационной кластерной структуры.

\section{Список использованных источников}

1. European Commission. Agriculture in the European Union - Statistical and Economic Information - Report 2010. - Luxembourg : Publications Office of the European Union, 2010. - 394 p.

2. European Commission. The CAP towards 2020. Meeting the food, natural resources and territorial challenges of the future. Communication to the European Parliament, the Council, the European Economic and Social Committee of the Regions. - Brussels, 2010.

3. Carayannis, E. Quadruple Innovation Helix and Smart Specialization: Knowledge Production and National Competitiveness / E. Carayannis, E. Grigoroudis. - Foresight and STI Governance, 2016. - P. 31-42.

4. Аграрная Европа в XXI веке / Э. Н. Крылатых [и др.] ; под общ. ред. Э. Н. Крылатых ; ФГУ «Ин-т Европы РАН». - М. : Летний сад, 2015. - 328 с.

5. Белоусова, Е. А. Тенденции развития европейских инновационных кластеров / Е. А. Белоусова // Экон. науки. - 2016. - № 4 (137). - С. 116-125. 